\title{
IMMOBILIZATION OF INVERTASE ON CARBOXYMETHYLCELLULOSE PREPARED FROM NATA DE COCO FOR THE INVERSION OF SUCROSE
}

\author{
E.O.V. Fundador, V.C. Sabularse*, M.A.J.R. Revilleza \\ Institute of Chemistry, University of the Philippines Los Banos College, \\ Laguna 4031, Philippines
}

Received 4 June 2002, Accepted 19 August 2002

\begin{abstract}
Nata de coco, the cellulose produced by Acetobacter aceti with coconut water as substrate, was used as starting material in the synthesis of carboxymethylcellulose after treatment with $\mathrm{NaOH}$ and monochloroacetic acid. The product, referred to as carboxymethyl-"nata" (CMN), had a degree of substitution of 0.76 , a higher value than those previously reported. This was used in the immobilization of invertase via ionic interaction and adsorptive forces, which produced a viscous colloidal suspension. Agar was incorporated to facilitate pellet formation. Interactions between the agar and the $\mathrm{CMN}$-invertase may have resulted from ionic interactions as well as H-bonding. The immobilized enzyme retained $71 \%$ of its initial activity and exhibited optimum $\mathrm{pH}$ of 4.5 and an optimum temperature of $55^{\circ} \mathrm{C}$. It was more sensitive to $\mathrm{pH}$ and temperature changes. The Michaelis constant, $\mathrm{K}_{\mathrm{m}}$, was $107.43 \mathrm{mM}$ for the immobilized enzyme, and 71.42 $\mathrm{mM}$ for the free enzyme. The $\mathrm{V}_{\max }$ values were $89.28 \mu$ mole $\min ^{-1}$ and $82.64 \mu$ mole min ${ }^{-1}$ for the free and immobilized enzyme, respectively. Statistical analyses showed that $V_{\max }$ values did not vary significantly. The higher $\mathrm{K}_{\mathrm{m}}$ of the immobilized enzyme may be attributed to diffusional effects, steric hindrance and conformational modifications of the enzyme. The immobilized enzyme has potential for further applications because of its stability with storage, repeated and continuous use.
\end{abstract}

\section{INTRODUCTION}

The growing popularity of high fructose syrups and artificial sweeteners has dampened the profitability of the sugar industry in the Philippines. In fact, high fructose syrups have replaced sucrose as an ingredient in commercially manufactured food and beverages. Glucose and fructose are sweeter than sucrose. Sucrose may be converted to glucose and fructose by the process of inversion. Invert sugar production may be conducted through the use of a bioreactor of invertase immobilized in an appropriate solid support like poly (vinyl) alcohol membrane ${ }^{1}$, gelatine membrane ${ }^{2}$, alginate gel $^{3}$ and diazotized 4-aminobenzoyl cellusose ${ }^{4}$. 
One possible solid support for the immobilization of invertase is carboxymethylcellulose (CMC). Carboxymethylcelluose can be synthesized from nata de coco, a bacterial cellulose produced by Acetobacter aceti, which is available all year round and can be produced in 2 to 3 weeks. The conversion of nata de coco into CMC would cut down the country's importation of this product and at the same time increase the market for nata de coco.

In this paper carboxymethylcellulose prepared from nata de coco will be referred to as carboxymethyl-nata or CMN.

\section{MATERIALS AND METHODS}

Nata de coco cubes were purchased from Davao City, dried and shipped by airfreight to the University of the Philippines Los Banos. Yeast invertase (E.C. 3.2.1.26) was obtained from Sigma Chemical Co. (St. Louis, MO, USA).

\subsection{Preparation of Carboxymethyl-nata with High Degree of Substitution}

The dried nata de coco cubes were allowed to rehydrate and then were reduced to small sized particles using a blender, washed and pressed three times to remove impurities and the acidic smell. The process of preparing carboxymethyl-nata was based on the optimal parameters employed by Manguiat and co-workers ${ }^{5}$ with some modifications. The procedure involved a two-cycle process of mercerization and etherification.

\subsection{Immobilization of Invertase}

A $0.1 \mathrm{~g}$ sample of crude yeast invertase was dissolved in $100 \mathrm{~mL} 0.1 \mathrm{M} \mathrm{pH} 4.5$ acetate buffer and stirred for about $25-30 \mathrm{~min}$ at $0.5^{\circ} \mathrm{C}$. One and a half grams of CMN was then added and the mixture stirred for $2 \mathrm{hr}$ at $0-5^{\circ} \mathrm{C}$.

An agar solution was prepared by mixing $1.5 \mathrm{~g}$ of agar in $100 \mathrm{~mL} 0.1 \mathrm{M}$ acetate buffer at $\mathrm{pH}$ 4.5 and heated to boiling. The solution was allowed to cool to $55^{\circ} \mathrm{C}$ and later mixed with the $\mathrm{CMN}$-invertase mixture at a volumetric ratio of $1: 1$. The resulting mixture was kept in a $40^{\circ} \mathrm{C}$ water bath and pelleted by forming uniform droplets on parafilm using a syringe. The pellets were kept at $0-5^{\circ} \mathrm{C}$ and allowed to solidify for $1 \mathrm{hr}$. The pellets were kept in $0.1 \mathrm{M}$ acetase buffer until further use. One $\mathrm{mL}$ of the solution (CMN-agar-invertase) contained $0.5 \mathrm{mg}$ of the crude invertase.

\subsection{Invertase Activity Assay}

Invertase activity was assayed using the procedure of Miller ${ }^{6}$ with some modifications. The activity of invertase for both the immobilized and the free enzyme was determined by incubating $40 \mathrm{~mL} 0.3 \mathrm{M}$ sucrose solution with $1 \mathrm{~mL}$ of the enzyme solution for 10 minutes in a $45^{\circ} \mathrm{C}$ water bath shaker. The reaction was terminated by adding $1 \mathrm{~mL}$ 3.5-dinitrosalicylic acid (DNSA) to 150-200 $\mu \mathrm{L}$ aliquot of the mixture. The mixture was then heated in a boiling water bath for 15 minutes, cooled to ambient temperature and diluted to a final volume of $20 \mathrm{~mL}$. A $0.2 \mathrm{~mL}$ aliquot of the resulting mixture was placed in each well of a flat bottom ELISA plate and the 
absorbance was read using an ELISA plate reader at $550 \mathrm{~nm}$. The concentration of the invert sugar was determined using a standard curve.

One unit of activity (U) is defined as the amount of reducing sugars produced (mmole) per minute at $45^{\circ} \mathrm{C}$ in $0.1 \mathrm{M} \mathrm{pH} 4.5$ acetate buffer containing $0.3 \mathrm{M}$ sucrose. Specific activity is expressed in $\mathrm{U} / \mathrm{mg}$ protein. The percent protein of the crude enzyme was $1.6 \%$. The relative activity was also calculated. This is equal to the activity value divided by the highest activity value for a particular run multiplied by 100 .

\subsection{Effect of CMN on Enzyme Retention}

The effect of CMN on the retention of invertase in the pellets was determined. Two types of pellets were prepared: one type contained $\mathrm{CMN}$, agar and the enzyme $(\mathrm{CMN}-1)$ and the control, which contained only agar and the enzyme $(\mathrm{CMN}-0)$. One $\mathrm{mL}$ of the pellets contained $0.5 \mathrm{mg}$ crude invertase.

One $\mathrm{mL}$ of each type of pellets was packed in a column with an inner diameter of $1.5 \mathrm{~cm}$. The pellets were washed with $200 \mathrm{~mL} 0.1 \mathrm{M} \mathrm{pH} 4.5$ acetate buffer. Inversion of sucrose was determined by loading $20 \mathrm{~mL} 0.3 \mathrm{M}$ sucrose solution in acetate buffer into the column and the reaction was allowed to proceed for $20 \mathrm{~min}$ at room temperature $\left(27-30^{\circ} \mathrm{C}\right)$. The amount of reducing sugars was then measured quantitatively. The activity of invertase in CMN-1 and CMN-0 were compared.

\section{Effect of invertase immobilization in CMN-agar pellets on enzyme activity.}

Fresh preparations of CMN-1 and CMN-0 were immediately placed in $40 \mathrm{~mL}$ of a $0.3 \mathrm{M}$ sucrose solution. The amount of reducing sugars rellesed was compared to that produced by the free enzyme.

\subsection{Characterization of the Immobilized Invertase}

Dependence of activity and binding on $\mathbf{p H}$. One $\mathrm{mL}$ of pellets was placed in $50 \mathrm{~mL}$ Erlenmeyer flasks and assayed for enzyme activity by adding $0.3 \mathrm{M}$ sucrose solution at varying $\mathrm{pH}$ $\left(3.5,4.0,4.5,5.0,5.5\right.$ and 6.0) and allowing inversion to proceed for $10 \mathrm{~min}$ at $45^{\circ} \mathrm{C}$. The solution was then separated from the pellets and $200 \mu \mathrm{L}$ aliquots were taken for reducing sugars determination. The hydrolysates were allowed to stand for 10 minutes at $45^{\circ} \mathrm{C}$ for further inversion of the residual sucrose and a second aliquot was taken and analyzed for reducing sugars.

The difference in the reducing sugar content of the first and second aliquots of the hydrolysates was representative of the amount of enzyme that leached out.

Dependence of invertase activity on temperature. The effect of temperature on invertase activity was determined by assaying the free and immobilized enzyme activities at 40, 45, 50, 55 and $65^{\circ} \mathrm{C}$. One $\mathrm{mL}$ samples of the prepared pellets were placed in a $50 \mathrm{~mL}$ Erlenmeyer flask into which $20 \mathrm{ml} 0.3 \mathrm{M}$ sucrose solution was added and the mixture was allowed to react for $10 \mathrm{~min}$. at the varying temperatures in a water bath shaker. One $\mathrm{mL}$ solutions containing free invertase $(0.5 \mathrm{mg}$ per $\mathrm{mL})$ were also assayed using the same conditions as that for the immo- 
bilized invertase.

Determination of the kinetic parameters. The activities of the free and immobilized enzyme were determined at sucrose concentrations of $0.02,0.04,0.06,0.08$ and $0.1 \mathrm{M}$. The reaction was allowed to proceed at $45^{\circ} \mathrm{C}$ for $10 \mathrm{~min}$. The amount of reducing sugars released was determined and from the these $\mathrm{K}_{\mathrm{m}}$ and $\mathrm{V}_{\max }$ were abtained using the Lineweaver-Burk plot.

Storage stability of the immobilized enzyme. The immobilized enzyme was kept at $0.5^{\circ} \mathrm{C}$ for 5 weeks. Enzyme activity was assayed every week. The assay was conducted by allowing 1 $\mathrm{mL}$ of the pellets to react in $20 \mathrm{~mL} 0.3 \mathrm{M}$ sucrose solution with a pH of 4.5 at room temperature.

Stability of the immobilized enzyme towards repeated use. The stability of the immobilized enzyme to repeated use was determined. One $\mathrm{mL}$ of the pellets containing the enzyme was placed in a column and allowed to react with $20 \mathrm{~mL} 0.3 \mathrm{M}$ sucrose for $10 \mathrm{~min}$ at room temperature and the amount of reducing sugars formed was measured. The pellets were then washed with $80 \mathrm{~mL}$ acetate buffer at $\mathrm{pH} 4.5$ and stored in buffer for $1 \mathrm{hr}$ at room temperature. This was repeated every hour for 10 hours.

Stability of the immobilized enzyme towards continuous use. One $\mathrm{mL}$ of the pellets was placed in 2 separate columns. In one column a $0.3 \mathrm{M}$ solution of analytical grade sucrose was allowed to continuously flow through. In the other column a $0.3 \mathrm{M}$ solution of commercial grade sucrose was used. Both runs were conducted for 7 hours at a flowrate of 0.4-0.8 mL5/ min and analyzed every hour for reducing sugars.

\section{RESULTS AND DISCUSSION}

\subsection{Preparation of Carboxymethyl-nata with a High Degree of Substitu- tion}

Carboxymethylcellulose with a degree of substitution of 0.76 was produced from nata de coco. This degree of substitution was higher than the reported value of 0.501 by Manguiat and Sabularse $^{7}$, and offered an excellent medium for ionic interaction as in the immobilization of enzymes, e.g. invertase.

\subsection{Immobilization of Invertase on Carboxymethyl-nata}

When the highly substituted CMN was dispersed in water in produced a viscous colloidal suspension which could not be directly used for ion exchange chromatography. Commercial preparations of insoluble carboxymethylcellulose suitable for ion exchange chromatography usually have a degree of substitution of less than 0.4 , which would then have less number of binding sites for proteins and enzymes. The CMN produced, which had a high degree of substitution would have more carboxyl groups available for the binding of the amino and other groups in proteins or enzymes. The greater number of binding sites in the highly substituted CMN should be taken advantage of in the preparation of the more active solid support. The strengthening of its constitution was realized by the incorporation of agar.

In theory, it may be possible to trap enzymes immobilized on CMN with a high degree of 
substitution in agar gels. Being a polymer with a large molecular weight the CMN-invertase will be retained inside the agar bead through noncovalent interactions.

Effect of CMN on enzyme retention. The CMN produced had the ability to disperse the enzyme at relatively high concentrations. This allowed a homogeneous distribution of the enzyme throughout the beads.

Table 1 shows the relative activity of the enzyme in invertase-agar beads (CMN-0) and in CMNinvertase-agar beads (CMN-1) after washing with $\mathrm{pH} 4.5$ phosphate buffer. It will be noted that the $\mathrm{CMN}-1$ beads had a higher activity than the $\mathrm{CMN}-0$ beads after each washing and that there was a decreasing trend in the activity in the $\mathrm{CMN}-0$ beads. Moreover, there was no change in the activity of the enzyme in the CMN-1 beads after each washing. These indicated that the enzyme leached faster from the $\mathrm{CMN}-0$ beads than from the $\mathrm{CMN}-1$ beads. Thus, the enzyme was possibly strongly bound to CMN.

Activity of invertase immobilized on CMN-agar pellets. Table 2 shows the relative activity of invertase in CMN-agar, in agar and in the native form. The enzyme in agar and in CMNagar had almost the same relative activity, $71 \%$ and $70 \%$, respectively. This indicated that the diffusion effect of CMN was negligible. The relatively higher activity of the native enzyme may be attributed to the fact that it was dispersed throughout the solution whereas the immobilized

Table 1 : Relative Activity of the Immobilized Enzyme After Successive Washings

\begin{tabular}{ccc}
\hline & \multicolumn{2}{c}{ Relative activity (\%) } \\
\cline { 2 - 3 } Washing & CMN-1 & CMN-0 \\
\hline 1st & 100 & 78.5 \\
2nd & 100 & 73.4 \\
3rd & 100 & 68.4 \\
\hline
\end{tabular}

Table 2: Relative Activity of Free and Immobilized Enzymes

\begin{tabular}{lc}
\hline & Relative Activity (\%) \\
\hline Native enzyme & 100 \\
Enzyme in agar (CMN-0) & 71 \\
Enzyme in CMN-agar (CMN-1) & 70 \\
\hline
\end{tabular}

enzyme was localized in the beads. Diffusional effects may also be attributed to the agar present. The diffusion coefficient of sucrose in agar was reported to be $80 \%$ of that in water at concentrations less than $0.1 \mathrm{M}$ and decreases appreciably above this point ${ }^{8}$.

\subsection{Characterization of Invertase}

Dependence of activity and binding on pH. Enzyme activity is affected by $\mathrm{pH}$. It was 
observed that the free and immobilized enzyme had a maximum activity at a $\mathrm{pH}$ value of 4.5 (Figure 1). Sabularse and Parayno 4 reported a similar value for native invertase and covalently immobilized invertase on the diazonium salt of p-aminobenzyl- "nata", a derivative of nata de coco. Results also indicated that invertase immobilized on CMN was more sensitive to $\mathrm{pH}$ changes. A possible explanation for this observation may be that the binding of the enzyme to CMN may have altered or modified the conformation of the native invertase into one that is affected by $\mathrm{pH}$ changes. $\mathrm{CMN}$ is negatively charged. The number of negative charges would be largely dependent on $\mathrm{pH}$. Since conformation of the enzyme is influenced largely by the ionic charges, $\mathrm{H}$-bonding and hydrophobic interactions in its microenvironment, a change in $\mathrm{pH}$

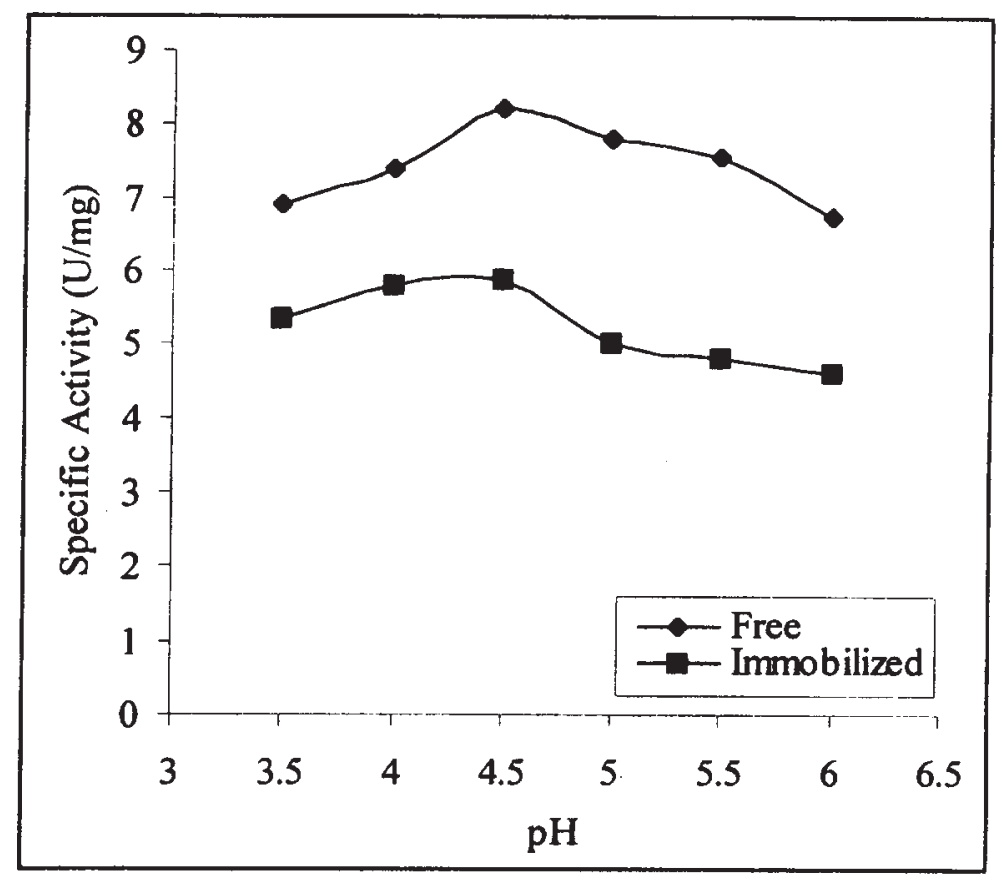

Figure 1 : Dependence of invertase activity on $\mathrm{pH}$.

would have a significant effect on its conformation. The $\mathrm{pH}$ could alter the charged state of some amino acid side groups that could be involved in substrate binding catalysis. This was also noted when tomato $\beta$-fructofuranosidase was adsorbed on $\mathrm{CMC}$ in the same $\mathrm{pH}$ range of 3.5$6.9^{9}$.

Ionic interactions and $\mathrm{H}$-bonding are important contributing factors to the immobilization and entrapment of invertase in the beads, which are dependent on $\mathrm{pH}$. The difference in the amount of invert sugar obtained from the solution assayed immediately after inversion and separation from the beads, and after allowing the filtrate to further stand for 10 minutes corresponds to the activity left in the solution or the amount of enzyme that leached out of the beads. Enzyme activity was measured instead of the amount of protein in the solution because the concentration of the enzyme that leached was too low to be detected by the sensitive Bradford methods.

Table 3 shows the relative activity of the enzyme that leached out of the beads. At $\mathrm{pH} 3.5$, it appeared that the enzyme was tightly bound to CMN because there was no activity detected in 
Table 3 : Effect of $p H$ on the Amount of Invertase Leached out of the CMN-INVERTASEAGAR Beads*

\begin{tabular}{cc}
\hline $\mathbf{p H}$ & \% Activity of enzyme leached out** \\
\hline 3.5 & $-0.05 \mathrm{a}$ \\
4.0 & $9.9 \mathrm{~b}$ \\
4.5 & $11.84 \mathrm{~b}$ \\
5.0 & $10.29 \mathrm{~b}$ \\
5.5 & $11.28 \mathrm{~b}$ \\
6.0 & $21.14 \mathrm{c}$ \\
\hline
\end{tabular}

* Mean of two replicates.

** Means followed by the same letter are not significantly different at a 5\% level using DMRT.

the solution after inversion. At this $\mathrm{pH}$, the carboxyl groups might still be protonated; hence suggesting the importance of $\mathrm{H}$-bond interaction between the enzyme and CMN. Since the enzyme retains its activity at this level, denaturation at a low $\mathrm{pH}$ can be ruled out. At higher $\mathrm{pH}$ values of 4.0-6.0, where carboxyl groups would have been neutralized to carboxylate, ionic interactions would have favored enzyme immobilization. Howerver, an increase in the enzyme

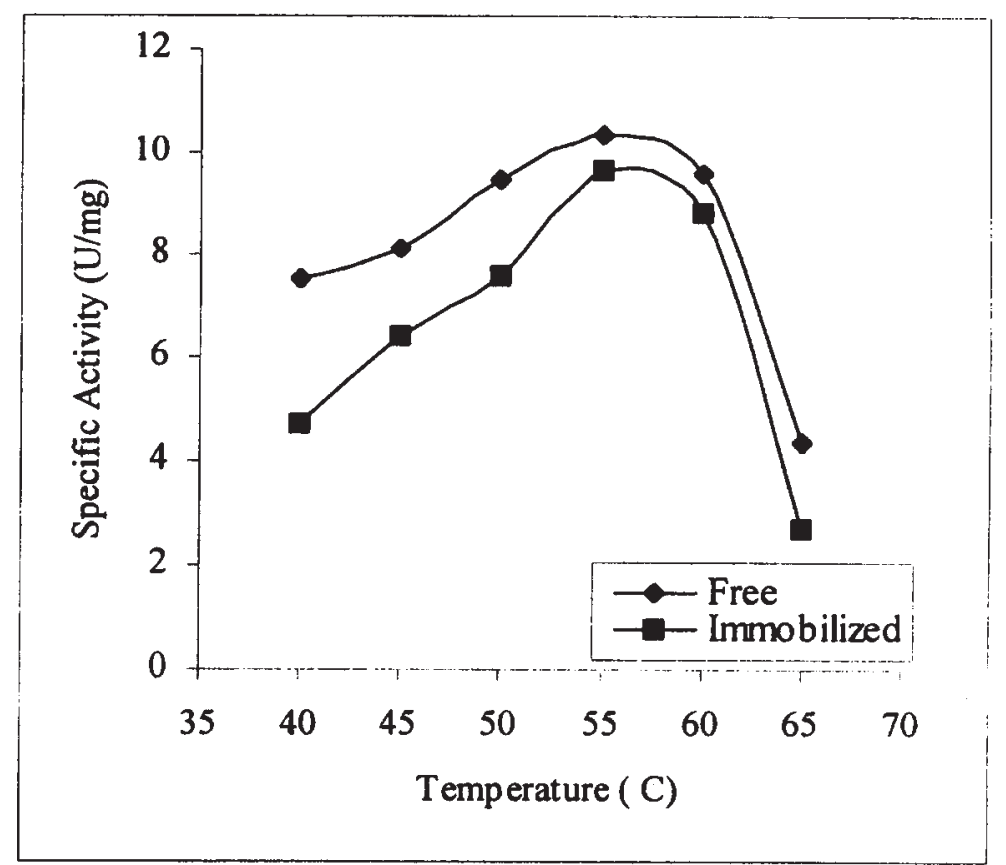

Figure 2: Effect of temperature on the specific activities of the free and immobilized enzymes.

activity in the supernate indicated otherwise. Again, this highlights the possibility that aside from ionic interactions, H-bonding is an important adsorptive force between invertase, CMN and agar. In addition, agar has sulfate groups that contribute to ionic interactions and other polar groups compatible for $\mathrm{H}$-bonding.

Effect of temperature. Figure 2 shows the effect of temperature on the activities of the 
immobilized enzyme and free enzyme. Both showed optimum activity at $55^{\circ} \mathrm{C}$ but the response of the immobilized enzyme was attenuated to some degree. A possible explanation for this is that when the enzyme is immobilized diffusion of the substrate to the enzyme active site contributes to the activity of the enzyme. Nakagawa and co-workers9 observed that tomato invertase embedded in acrylamide was significantly sensitive to temperature changes from $12-30^{\circ} \mathrm{C}$. Similarly, Imai and co-workers ${ }^{10}$ reported that yeast invertase immobilized in polyvinyl alcohol showed increased sensitivity towards temperature changes. It would seem that temperature sensitivity changes in embedded enzymes were more significant at cooler temperatures. Diffusion is a function of temperature, which increases in rate with increase in temperature. At cooler

Table 4 : Kinetic Parameters of Free and Immobilized Invertase

\begin{tabular}{ccc}
\hline & Free enzyme & Immobilized enzyme \\
\hline $\mathrm{K}_{\mathrm{m}}$ & $71.42 \mathrm{mmolar}$ & $107.43 \mathrm{mmolar}$ \\
$\mathrm{V}_{\max }$ & $89.28 \mu \mathrm{mole} / \mathrm{min}$ & $82.64 \mu \mathrm{mole} / \mathrm{min}$ \\
\hline
\end{tabular}

temperatures diffusion may be rate limiting but at higher temperatures diffusion may be less rate limiting. Thus, at higher temperatures diffusion effects may be eliminated and enzyme activity approaches that of the free enzyme. Diffusion effects may play a very significant role at low temperatures.

Kinetic Parameters. The kinetic parameters of the immobilized and free invertase are given in Table 4. The $\mathrm{K}_{\mathrm{m}}$ of the free enzyme was lower than that of the immobilized enzyme. This may be due to a lower concentration of the substrate inside the beads than that in solution because of diffusion effects. In the immobilization of yeast invertase in agar beads, it was observed that $\mathrm{K}_{\mathrm{m}}$ increased with bead size ${ }^{8}$ as a result of the difficulty of the substrate reaching the active sites. The diffusion coefficient of sucrose in water at $50^{\circ} \mathrm{C}$ was reported to be $5.6 \times 10^{-4} \mathrm{~cm}^{2} / \mathrm{min}^{8}$.

The $V_{\max }$ of the free enzyme was slightly higher than that of the immobilized enzyme. This may be attributed to the possibility that not all the enzyme molecules entrapped in the agar were accessible to the substrate especially those located in the innermost part of the beads. The immobilization process may also have slightly changed the conformation of the enzyme. Conformation of the enzyme dictates its activity.

Statistical analyses however, showed that the $\mathrm{V}_{\max }$ of the free and bound enzyme did not vary significantly. This probably indicated that steric hindrance was negligible considering the molecular mass of sucrose being 342. Andrew ${ }^{12}$ reported that sucrose traveled slowest in a column with $9 \%$ agar compared to other substances, which was attributed to sucrose being able to penetrate the pores of the gel. Pore size of agar is dependent upon agar concentration. Dilute agar solutions would produce gels with larger pores ${ }^{13}$. The concentration of the agar used in the beads was $0.75 \%$. At this concentration access ob sucrose to the immobilized enzyme's active sites may be greater. Thus, the beads produced from agar were ideal for entrapping the CMN-invertase complex. 
Storage Stibility. The effect of storage on immobilized invertase is shown in Figure 3. Statistical analyses using CRD and DMRT showed no significant change in enzyme activity when

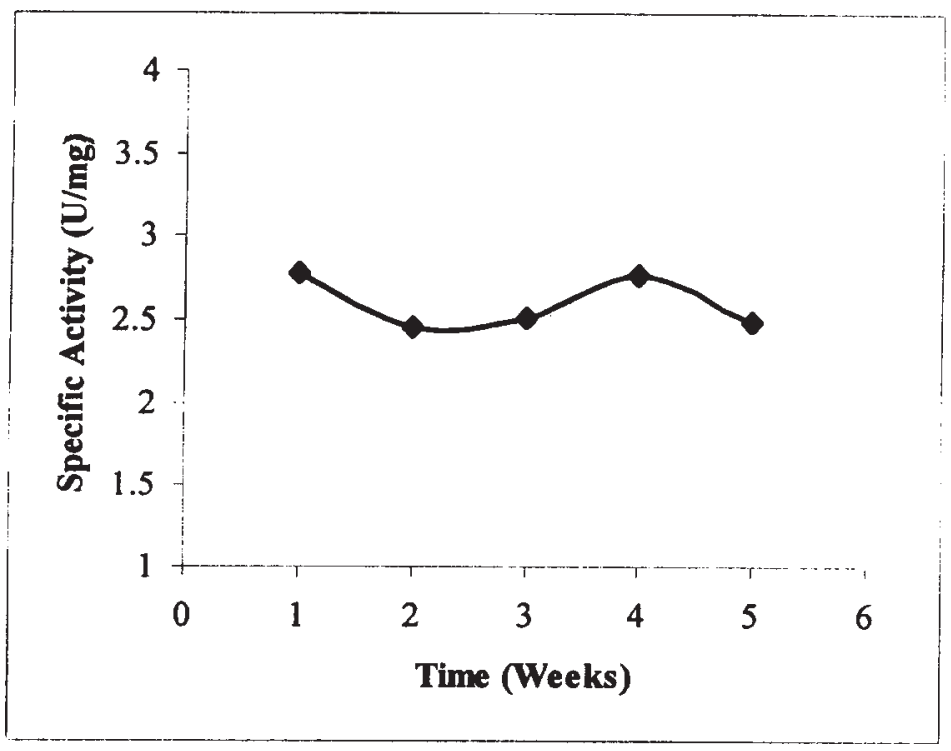

Figure 3 : Storage stability of immobilized ivertase.

assayed from week 1 to week 5 . This could be attributed to enhanced stability of the enzyme by immobilization resulting in the preservation of the enzyme conformation. The rigidity in conformation may be accounted for by the ionic and adsorptive properties of the CMN and possibly, the interactions with agar.

Stability Towards Repeated Use. The effect of repeated use on the stability of the immobilized enzyme is shown in Figure 4. Enzyme activity was noted even on the 10th cycle. An

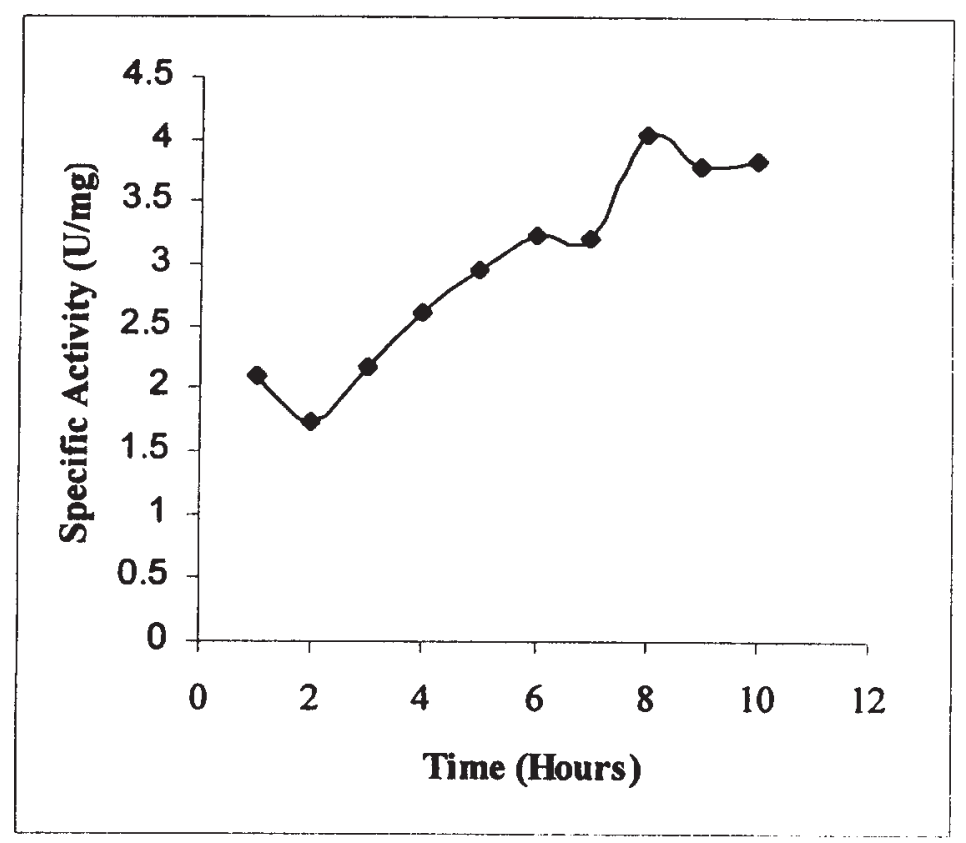

Figure 4 : Stability of immobilized invertase towards repeated use. 
increasing trend in enzyme activity was noted from the first hour to the seventh hour. This increase in activity may be due to the presence of residual sucrose adsorbed in the beads.

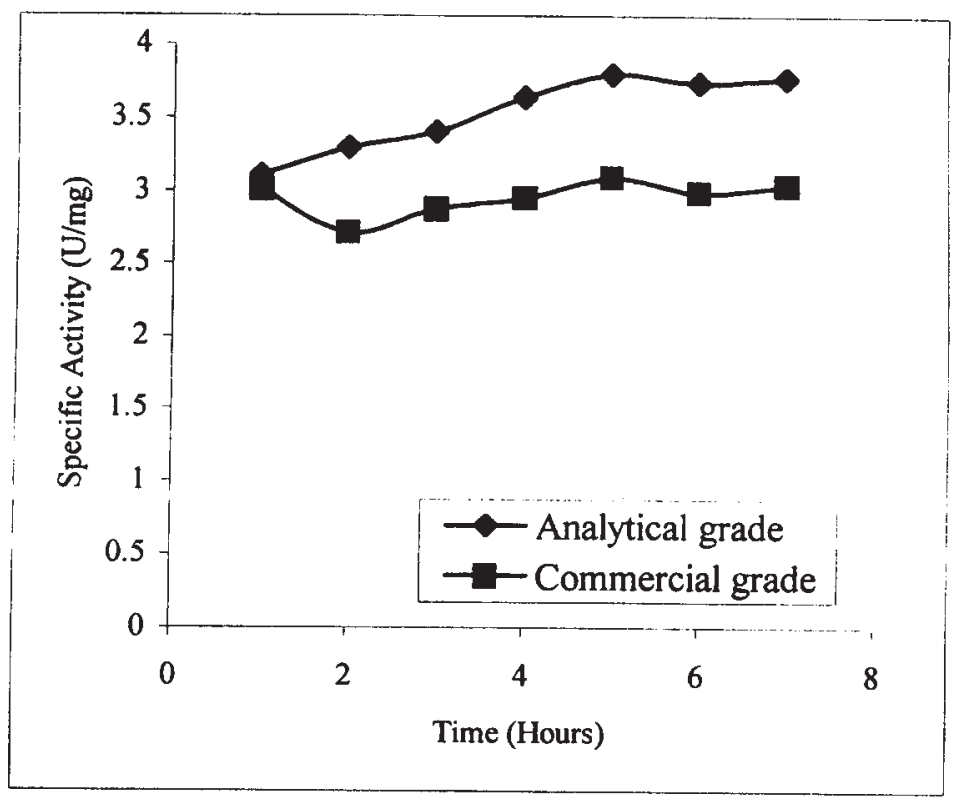

Figure 5: Effect of continuous use on invertase activity using commercial and analytical grade sucrose

Sucrose may have been effectively adsorbed on the beads and was not efficiently washed off. DMRT analysis whowed no significant difference in the 6th, 8th, 9th and 10th runs. There was no indication of a loss in activity for all runs.

Stability Towards Continuous Use. The effect of continuous use on immobilized invertase activity using table sugar and analytical grade sucrose is shown in Figure 5.

Analysis of variance showed no significant differences in activity of the enzyme at a $1 \%$ level using table sugar as substrate. However, for analytical grade sucrose significant differences were observed at the $1 \%$ level. Using DMRT, there were no significant changes in activity for table sugar through the whole run. A significant difference was noted for invertase activity using analytical grade sucrose from the 1 st to the 3rd hour at a 5\% level but no significant differences from the 4th to the 7th hour. An increase in activity using analytical grade sugar was noted. It is possible that some time was required for sucrose to fully enter beads and after three hours a steady wstate may have been attained.

\section{CONCLUSIONS}

The improved CMN had twice the degree of substitution (DS = 0.76) compared to that of a previously synthesized CMN (DS $=0.501)$ by Manguiat and co-workers 5 .

Crude yeast in vertase was immobilized on the $\mathrm{CMN}$, mixed with agar to form pellets on parafilm at $0.5^{\circ} \mathrm{C}$, and stored at the same temperature at $0.1 \mathrm{M} \mathrm{pH} 4.5$ acetate buffer. 
The effect of $\mathrm{pH}$ on the binding of the enzyme to the carrier was determined by measuring the enzyme activity left in the filtrate after separation from the beads. No activity was noted in the filtrate at $\mathrm{pH}$ 3.5. Activities were observed in the filtrate at $\mathrm{pH} 4.0$ to 6.0. The influence of the structure and functional group charge on immobilization is dependent upon $\mathrm{pH}$ especially if binding is through ionic interactions and H-bonding.

The optimum $\mathrm{pH}$, temperature and kinetic properties of the immobilized invertase was investigated and compared to that of the free enzyme. Both showed similar optimal conditions for activity, however, the immobilized enzyme showed increased sensitivity to $\mathrm{pH}$ and temperature changes. The $\mathrm{V}_{\max }$ was found to be $89.28 \mu \mathrm{mole} / \mathrm{min}$ and $82.64 \mu \mathrm{mole} / \mathrm{min}$ and $\mathrm{K}_{\mathrm{m}}$ was found to be $71.42 \mathrm{mM}$ and $107.43 \mathrm{mM}$ sucrose for the free and immobilized enzymes, respectively.

The stability of the immobilized enzyme was evaluated against storage and repeated use using analytical grade sucrose. Analytical grade sucrose and table sugar were used to determine the stability towards continuous use. No significant loss in activity was found in the both determinations.

\section{ACKNOWLEDGEMENTS}

The authors wish to acknowledge the support of the Philippine Council for Advanced Science and Technology (PCASTRD), Department of Science and Technology (DOST) and the Institute of Chemistry, College of Arts and Sciences, University of the Philippines Los Banos.

\section{REFERENCES}

1. T, Shiomi, Tohyama, M., Satoh, M., Miya, M. and K. Imai (1988), Biotechnol Bioeng, 32, pp. 664-668.

2. Russo, P.A., Garofalo, A., Bencivenga, U., Rossi, S., Castagnolo, D. and DG. Mita. (1996), Biotechnol. Appl. Biochem, 23, pp. 141-148.

3. Yoshii, H., Obana, H., Koyama, Y., Hikuma, M. and Yoshimura, M. (1993), J. Agri. Chem. Soc, 67, pp. 1569-1574.

4. Sabularse, D.C. and Parayno, N. A. (1993), Microbial Utilization of Renewable Resources, P. Matangkasombut and Y. Oshima, (eds). International Center for Cooperative Research on Biotechnology. Japan. Osaka Univ., Osaka, Japan, 8, pp. 77.

5. Manguiat, L.S., Sabularse, V. C. and Sabularse, D.C (2001) ASEAN J. Sci.Tech. Dev., 18, pp. 85-96.

6. Miller L. (1959), Anal. Chem, 113, pp. 426-428.

7. Manguiat, L.S. and Sabularse, V. C (1996), The UP Home Economics Journal,College of Home Economics, University of the Philippines, Quezon City, vol. 23-24,pp. 14-30.

8. Toda, K and Shoda, A.M. (1975), Biotechnol. Bioeng, 17, pp. 481-497.

9. Nakagawa, H., Arao, T., Matsuzawa, T., Ito, S., Oguran, N. and Takihana, H. (1975), Agri. Biol. Chem, 39, pp. 1-5.

10. Imai, K., Shiomi, T., Sato, K., and Atsuyoshi, F. (1983), Biotechnol. Bioeng,25, pp. 613-617.

11. Henrion, P. (1963), Biotechnol. Bioeng,15, pp. 134-139.

12. Andrew, P. (1964), Biochem. J., 91, pp. 222-232.

13. Andrew, P. (1962), Nature,196, pp. 36-39. 